\title{
The Role of Human Resource Practices for the Development of Operator 4.0 in Industry 4.0 Organisations: A Literature Review and a Research Agenda
}

\author{
Emanuele Gabriel Margherita ${ }^{1, *(\mathbb{D})}$ and Ilenia Bua ${ }^{2}$ (D) \\ 1 Department of Economics Engineering Society and Business Organization—DEIM, University of Tuscia, \\ Via del Paradiso 47, 01100 Viterbo, Italy \\ 2 Department of Economics and Business Sciences and Law for Economics Di.SEA.DE, University of Milan \\ Bicocca, Piazza dell'Ateneo Nuovo 1, 20126 Milano, Italy; ilenia.bua@unimib.it \\ * Correspondence: emargherita@unitus.it
}

check for updates

Citation: Margherita, E.G.; Bua, I. The Role of Human Resource Practices for the Development of Operator 4.0 in Industry 4.0 Organisations: A Literature Review and a Research Agenda. Businesses 2021, 1, 18-33. https://doi.org/ 10.3390/businesses1010002

Academic Editor: Cristina Raluca Gh. Popescu

Received: 20 March 2021

Accepted: 13 April 2021

Published: 19 April 2021

Publisher's Note: MDPI stays neutral with regard to jurisdictional claims in published maps and institutional affiliations.

Copyright: (c) 2021 by the authors. Licensee MDPI, Basel, Switzerland. This article is an open access article distributed under the terms and conditions of the Creative Commons Attribution (CC BY) license (https:// creativecommons.org/licenses/by/ $4.0 /)$.

\begin{abstract}
In this study, we summarised the human resources practices for the development of Operator 4.0. Operator 4.0 is the worker operating in an Industry 4.0 organisation. Such organisations introduce novel digital technologies—including Big Data, robotics, and the Internet of Things—along the assembly line. Operators 4.0 can manage Industry 4.0 technologies, and Industry 4.0 technologies also support their activities. Some studies illustrate the enabling Industry 4.0 technologies for this role and the various qualitative benefits for Operator 4.0. However, organisations encounter issues to prepare traditional manufacturing workers for this novel role, which implies a drastic change in training and designing jobs, particularly for the qualitative aspects of the work organisation and human-computer interaction. Moreover, traditional manufacturing workers do not possess the proper digital skills to manage complex Industry 4.0 technology. Thus, there is a lack of study that illustrates what organisational practices are used to develop an Operator 4.0. Human resources management is the organisational function devoted to these challenges, such as a lack of a skilled workforce in handling high-tech technologies and employee retention. It provides human resource practices to develop workers for their role. Therefore, we addressed this gap by conducting a systematic literature review to summarise the used human resource practices for the development of an Operator 4.0. The results show six human resource practices for developing an Operator 4.0: staffing, job design, training, performance appraisal system, knowledge management, and compensation. We concluded by proposing a research agenda to advance this research stream.
\end{abstract}

Keywords: Operator 4.0; human resource practices; human resource management; Industry 4.0; Industry 5.0; socially sustainable factory

\section{Introduction}

Over the recent years, manufacturing organisations have been adopting Industry 4.0 technologies-including Big Data, robots, and the Internet of Things-to enhance their production process $[1,2]$. Industry 4.0 adoption allows a higher level of automation through the vertical and integral integration of production systems. The vertical integration is internal to the organisation and represents the integration of several units within an organisation. Horizontal integration refers to the digital information sharing that facilitates collaboration among partners within a supply chain, including the customer $[3,4]$.

The extant literature depicts two perspectives of the Industry 4.0 adoption. The technocentric perspective considers Industry 4.0 technologies as the main driver to improve organisational performance by automating the production process and reducing workers' roles along the assembly line. Thus, manufacturing organisations can also reduce staff costs because workers are unnecessary [5]. In contrast, the perspective of a socially sustainable factory or Industry 5.0 deems Industry 4.0 adoption as a complex socio-technical 
system $[6,7]$. Workers play a crucial role in the organisation because they cooperate and manage Industry 4.0 technologies [8]. The interplay between workforce and Industry 4.0 technologies improves and maintains an efficient production process [9]. Our study used the latter perspective studying the role of workers in an Industry 4.0 organisation called Operator 4.0. The literature stream of Operator 4.0 is in infancy. Operator 4.0 refers to "a smart and skilled operator who performs not only cooperative work with robots but also work aided by machines" [10].

Industry 4.0 adoption allows novel forms of human-machine interactions [11]. Operator 4.0 can interact with Industry 4.0 technologies, physically and cognitively. Such interplay delivers qualitative benefits to Operator 4.0 in terms of a more enjoyable working environment, greater autonomy, and self-development [12,13]. In addition, Industry 4.0 automation reduces demanding muscular activities and the exposure to hazards of Operator 4.0. Thus, Operator 4.0 takes on supervision activities on Industry 4.0 technologies in a safer workplace [14]. This supervision role is also facilitated by a smart assistant that guides such tasks [15].

However, the extant literature reports various issues that organisations encounter to hire a suitable human resource for this role or to develop Operator 4.0 by requalifying traditional manufacturing workers. Indeed, such workers possess operational competencies related to the usage of traditional technologies and in the assembly of products [16]. They do not possess digital competencies to manage complex Industry 4.0 technologies $[17,18]$. Moreover, some studies revealed that the workers are not motivated to use these technologies, which may lead to an economic loss or the rejection of the Industry 4.0 adoption $[19,20]$. Therefore, there is a literature gap that explores what organisational practices are used to develop an Operator 4.0.

Human resource management is the function that faces these challenges in organisations [21]. It provides human resources practices to create favourable conditions for workforce development to accomplish their job $[13,22]$. Human resource practices involve the up-skill of workers to manage these novel technologies, hire novel workers for the desired role, and retain valuable workers [23]. Human resource practices also aim to maintain a higher level of knowledge, competencies, and workforce capabilities for better job performance [24].

Therefore, we addressed this literature gap by conducting a systematic literature review summating the human resource practices to develop an Operator 4.0. The study answered the research question: "What are the human resource practices for the development of Operator 4.0?".

We contributed to the literature proposing a human resource perspective for the development of Operator 4.0 by summarising six human resource practices that complement the engineering perspective of Operator 4.0. We then proposed a research agenda to create a theory of the human resource practices for Operator 4.0 development and advance this research stream.

The structure of the paper is as follows. In Section 2, we introduce the theoretical framing of the paper. In Section 3, we describe the research design, and we illustrate the study findings in Section 4. In Section 5, we discuss the study results, and we propose a research agenda for future research avenues. We conclude the study in Section 6.

\section{Theoretical Framework}

In this section, we present the literature on Operator 4.0 and the human resource management for the development of Operator 4.0.

\subsection{Operator 4.0}

Operator 4.0 (OP40) refers to the manufacturing worker operating in Industry 4.0 (I40) organisations. This role is the evolution of traditional manufacturing workers with manual skills that conducted assembly activities using mechanical technologies. The extant literature distinguishes three types of a traditional manufacturing worker. Operator 1.0 
conduced manual and dexterous work with some support from mechanical tools and manually operated machine tools. Operator 2.0 performed assisted work with the support of computer tools-such as computerised numerical control machines-and information systems. Operator 3.0 accomplished tasks by cooperating with robots, other pieces of machinery, and computer tools [25].

In contrast, OP40 works in an Industry 4.0 assembly line, where I40 technologies allow for higher automation of production activities [3]. Manual activities, such as the assembly or handling of products, are conducted by these novel technologies [26]. Thus, OP40 is in charge of collaborating, managing, and supervising these advanced technologies, and simultaneously these technologies support OP40 activities [10]. The derived sociotechnical interplay maintains constant and efficient production [9].

I40 adoption enables new forms of interactions between operators and technologies, which are cognitive and physical interactions [27-29]. Wearable trackers enable both interactions, and these technologies allow for the tracking and monitoring of operator activities, heart rate, health-related metrics, and GPS location [27].

The enabling technologies for cognitive interactions are [10,15]:

- Augmented reality is a technology enriching the real-world factory environment with digital information and media overlaid in real-time in her field of view by head-gear.

- Virtual reality creates a computer-simulated word replicating a manufacturing environment with virtual objects.

- Enterprise social networks, embedded in mobile devices, allow communicating with operators and share real-time information regarding the production status and knowledge about production activities.

- Intelligent personal assistance, a software agent or artificial intelligence, facilitates the interaction with the human-machine interface of I40 technologies, computers, and information systems.

- Big Data refers to a mix of technologies that analyse unstructured or semi-structured data extracted from I40 technologies to discover information about the production process.

- The enabling technologies for physical interactions are [30]

- The smart exoskeleton is a wearable mobile machine that facilitates limb movement with increased strength and endurance through electric motors, pneumatics, and lever.

- Cobots are robots designed to collaborate with humans in safety. Cobots perform various hard muscular, repetitive, and non-ergonomic activities related to the movement and manipulations of objects faster than workers.

Moreover, the extant literature reports various qualitative benefits that I40 adoption has on OP40, which address manufacturing workers' issues during their activities. Traditional manufacturing workers suffer from the physical workload and cognitive load due to their operational activities [31]. Activities related to handling heavy products and repetitive assembly movements contribute to creating the physical workload. I40 adoption can address these issues by automating non-ergonomic body movements and postures through cobots to avoid strain or injury and monitor physical data to prevent possible physical workload [32]. In addition, the exoskeleton adoption reduces human physical efforts during several manual tasks, and therefore, it can reduce work fatigue and increase operator productivity [32]. Big Data analysis allows predicting relevant and critical events along the assembly line, such as the breaks of machinery pieces or lack of lubrication of the conveyor belt. Thus, OP40 can better forecast potential machinery issues to maintain constant production and safety in a more stimulating workplace.

Furthermore, the manufacturing operator experiences mental load due to the conduction of daily activities. Manufacturing workers experienced difficulties in conducting assembly activities and supervising technologies. Still, the operator experiences issues in recollecting products and material in handling different computer systems.

The adoption of virtual and augmented reality addresses these issues by supporting real-time operator training, maintenance, and complex activities with a digital assistance system, thus reducing human errors [12,15]. 
The adoption of enterprise social networks accelerates the generation of ideas for product and process innovation. In addition, it facilitates the problem-solving of OP40 by interconnecting operators with the organisation's punctual information [31].

Adopting intelligent personal assistance provides vocal guidance to OP40, which helps them with their activities. The personal analytics of OP40, extracted from the wearable trackers, can be used to plan their work shifts better to reduce their physical and cognitive workload due to their operational activities along the production line [12].

\subsection{Human Resource Management}

The human resource department, previously called personnel management, is the organisational function that deals with these challenges because it is in charge of organising human resource management (HRM) [21]. HRM is a systematic approach that provides practices to support all aspects of the employee life cycle, from recruitment to exit [23]. More specifically, HR practices for a complex work environment cover staffing activity to seek and hire valid personnel for the desired role. Then, HR practices involve training activities to prepare workers for their job position and collaborate technologies and practices to sustain personnel's high performance, such as performance appraisal system and knowledge management and reward systems [24]. HRM is also in charge of creating a changing culture and favourable conditions for the I40 adoption [22,33]. That contributes to reducing avoid resistance to change and low motivation of workers that have to use I40 technologies $[17,18]$.

Therefore, HR practices are recognised as a fundamental part of the organisation because they support organisational performance and shape a sustainable advantage based on highly skilled personnel. That is not easy to imitate from competitors [34].

In I40 organisations, HRM follows an upskill strategy [29] because OP40 activities are demanding digital and analytical skills due to the novel I40 technologies $[17,35]$.

Indeed, I40 technologies use complex systems embedded in the human-computer interface that allow more advanced technology management and remotely [36]. OP40 can start, block, and change movement or activities of technologies, and this requires that organisations train workers to develop digital skills to deal with these technologies [37]. Thus, HRM supports the shifts from a production-centric worker, who mainly possesses manual skills for the assembly of products and can manage simple human-computer interface [14] to knowledge and data-driven OP40 [38] who has a profound understanding of the I40 technologies and overall production process [39].

In doing so, HR practices concentrate their effort on developing soft and hard skills for workers. Soft skills are a cluster of personality traits that have a synergistic effect, contributing decisively to personal and professional effectiveness. They involve transversal skills to manage social interactions in a professional environment. Hard skills describe a specific set of technical and digital skills to manage I40 technologies [40].

\section{Research Design}

We conducted a systematic literature review to summarise the HR practices for the development of OP40 from January 1st to January 31th 2021, using the Scopus database, Google Scholar, and Science Direct [41]. To this end, we used the following research query: "Industry 4.0" OR “Operator 4.0" AND "Human Resourc *" OR "Human Resource Management" OR "Human Resource Practic *". We refined the research by selecting articles in English and from the Business, Management, and Accounting subject area. Although some scholars recommend excluding conference proceedings from a literature review [42], the present study included them to extract insights relating to this emerging research area [43]. Table 1 illustrates the literature research. 
Table 1. Details of the literature search (* represents any characters).

\begin{tabular}{|c|c|}
\hline Item & Description \\
\hline Source & Scopus, Google Scholar, and Science Direct \\
\hline Query & $\begin{array}{l}\text { TOPIC: “Industry 4.0" OR “Operator 4.0" "AND Human Resourc *" } \\
\text { OR “Human Resource Management" OR "Human Resource Practic *". } \\
\text { Refined by: LANGUAGES: (ENGLISH), Subject Area: Business, } \\
\text { Management and Accounting, Source Type: Journals }\end{array}$ \\
\hline Hits & 250 \\
\hline \multicolumn{2}{|l|}{ Papers retained after: } \\
\hline - $\quad$ Title and abstract selection & 85 \\
\hline - $\quad$ Full-text selection & 30 \\
\hline - $\quad$ Backward and forward search & 43 \\
\hline
\end{tabular}

The query released 250 articles. We removed all the papers with incomplete bibliographic data points, duplicates, and an abstract in English and the remaining text in a different language. The data analysis aimed to detect the proper HR practices for OP40. To this end, one co-author conducted the screening of the abstract of each article in order to assess its relevance with our research objectives. We included in the review both conceptual and empirical papers that mention HRM or HR practices for OP40 and in I40 organisations. In this phase, we excluded some articles discussing different industry settings from the manufacturing industry and those articles using I40 as a short point of reference or as a collateral research topic. A total of 85 papers were selected for the final review.

The selected papers were then thoroughly read, and we reached a group of 30 papers that illustrate HR practices for OP40 development [41]. We concluded the review by conducting a backward references search to reinforce the result of our literature review [44]. Each of the remaining articles was analysed by two co-authors independently. Then, some joint meetings were held by the two authors to compare the results and, where required, make verification to reach a consensus. The final query produced 43 papers which we used to identify the HR practices for OP40 development.

\section{Findings}

The literature review was based on 43 articles, which are reported in Table 2. Most of the articles illustrate one HR practice to develop OP40. In contrast, some studies argue that organisations employ various HR practices for OP40.

Table 2. Results of the systematic literature review (C.Proc. indicates conference proceedings).

\begin{tabular}{|c|c|c|c|c|c|c|c|c|}
\hline \multirow[b]{2}{*}{ Article } & \multirow[b]{2}{*}{ Year } & \multirow{2}{*}{$\begin{array}{l}\text { Source } \\
\text { Type }\end{array}$} & \multicolumn{6}{|c|}{ HR Practices for OP40 Development } \\
\hline & & & Staffing & $\begin{array}{c}\text { Job } \\
\text { Design }\end{array}$ & Training & $\begin{array}{l}\text { Performance Appraisal } \\
\text { System }\end{array}$ & $\begin{array}{l}\text { Knowledge } \\
\text { Management }\end{array}$ & Compensation \\
\hline Romero et al. & 2016 & C. Proc. & $\sqrt{ }$ & & & & & \\
\hline Marvel et al. & 2016 & Journal & $\sqrt{ }$ & & & & & \\
\hline Onik et al. & 2018 & C. Proc. & $\sqrt{ }$ & & & & & \\
\hline Waschull et al. & 2017 & C. Proc. & $\sqrt{ }$ & & & & & \\
\hline Vrchota et al. & 2020 & Journal & $\sqrt{ }$ & & & & & \\
\hline $\begin{array}{l}\text { Sivathanu and } \\
\text { Pillai }\end{array}$ & 2018 & Journal & $\sqrt{ }$ & $\sqrt{ }$ & & & & $\sqrt{ }$ \\
\hline Alhajjar et al. & 2018 & Journal & & $\sqrt{ }$ & & & & $\sqrt{ }$ \\
\hline Shamim et al. & 2016 & C. Proc. & $\sqrt{ }$ & $\sqrt{ }$ & $\sqrt{ }$ & $\sqrt{ }$ & & $\sqrt{ }$ \\
\hline $\begin{array}{l}\text { Kadir and } \\
\text { Broberg }\end{array}$ & 2021 & Journal & & $\sqrt{ }$ & & & & \\
\hline Gan and Yusof & 2019 & Journal & & $\sqrt{ }$ & & & & $\sqrt{ }$ \\
\hline
\end{tabular}


Table 2. Cont.

\begin{tabular}{|c|c|c|c|c|c|c|c|c|}
\hline \multirow[b]{2}{*}{ Article } & \multirow[b]{2}{*}{ Year } & \multirow{2}{*}{$\begin{array}{l}\text { Source } \\
\text { Type }\end{array}$} & \multicolumn{6}{|c|}{ HR Practices for OP40 Development } \\
\hline & & & Staffing & $\begin{array}{c}\text { Job } \\
\text { Design }\end{array}$ & Training & $\begin{array}{l}\text { Performance Appraisal } \\
\text { System }\end{array}$ & $\begin{array}{c}\text { Knowledge } \\
\text { Management }\end{array}$ & Compensation \\
\hline $\begin{array}{l}\text { Gabriel and } \\
\text { Pessel }\end{array}$ & 2016 & Journal & & $\sqrt{ }$ & & & & \\
\hline Romero et al. & 2018 & C. Proc. & & $\sqrt{ }$ & & & & \\
\hline Zolotová et al. & 2020 & Journal & & $\sqrt{ }$ & & & & \\
\hline $\begin{array}{l}\text { Braccini and } \\
\text { Margherita }\end{array}$ & 2019 & Journal & & & $\sqrt{ }$ & & & \\
\hline Kraiger et al. & 2004 & Journal & & & $\sqrt{ }$ & & & \\
\hline Santhanam et al. & 2008 & Journal & & & $\sqrt{ }$ & & & \\
\hline $\begin{array}{c}\text { Margherita and } \\
\text { Braccini }\end{array}$ & 2021 & Journal & & & $\sqrt{ }$ & & & \\
\hline Hecklau et al. & 2016 & C. Proc. & & & $\sqrt{ }$ & & & \\
\hline Van Der Sluis & 2004 & Journal & & & $\sqrt{ }$ & & & \\
\hline Fettig et al. & 2018 & C. Proc. & & & $\sqrt{ }$ & & & \\
\hline Chen and Huang & 2009 & Journal & & & $\sqrt{ }$ & & & $\sqrt{ }$ \\
\hline $\begin{array}{c}\text { Prieto and } \\
\text { Pérez-Santana }\end{array}$ & 2014 & Journal & & & $\sqrt{ }$ & & & \\
\hline $\begin{array}{l}\text { Benešová and } \\
\text { Tupa }\end{array}$ & 2017 & C. Proc. & & & $\sqrt{ }$ & & & \\
\hline Gehrke & 2015 & Journal & & & $\sqrt{ }$ & & & \\
\hline Rada & 2015 & $\begin{array}{l}\text { Web } \\
\text { Article }\end{array}$ & & & $\sqrt{ }$ & & & \\
\hline Tisch et al. & 2013 & C. Proc. & & & $\sqrt{ }$ & & & \\
\hline Peruzzini et al. & 2020 & Journal & & & $\sqrt{ }$ & & & \\
\hline Mavrikios et al. & 2013 & Journal & & & $\sqrt{ }$ & & & \\
\hline Fletcher & 2001 & Journal & & & & $\sqrt{ }$ & & \\
\hline Kaasinen et al. & 2020 & Journal & & & & $\sqrt{ }$ & $\sqrt{ }$ & \\
\hline $\begin{array}{l}\text { DeNisi and } \\
\text { Pritchard }\end{array}$ & 2006 & Journal & & & & $\sqrt{ }$ & & \\
\hline $\begin{array}{l}\text { Margherita and } \\
\text { Braccini }\end{array}$ & $2020 \mathrm{~b}$ & Journal & & & & $\sqrt{ }$ & & \\
\hline Li et al. & 2019 & Journal & & & & $\sqrt{ }$ & & $\sqrt{ }$ \\
\hline $\begin{array}{l}\text { Militello and } \\
\text { Hutton }\end{array}$ & 1998 & Journal & & & & $\sqrt{ }$ & & \\
\hline Woźniak et al. & 2014 & Journal & & & & $\sqrt{ }$ & & \\
\hline Ruppert et al. & 2018 & Journal & & & & & $\sqrt{ }$ & \\
\hline $\begin{array}{l}\text { Davenport and } \\
\text { Prusak }\end{array}$ & 1998 & Journal & & & & & $\sqrt{ }$ & \\
\hline Pinzone et al. & 2020 & Journal & & & & & $\sqrt{ }$ & \\
\hline Roblek et al. & 2016 & Journal & & & & & $\sqrt{ }$ & \\
\hline Gerdin et al. & 2020 & C. Proc. & & & & & $\sqrt{ }$ & \\
\hline Romero et al. & 2016 & C. Proc. & & & & & $\sqrt{ }$ & \\
\hline Wolf et al. & 2018 & Journal & & & & & & $\sqrt{ }$ \\
\hline Johnson et al. & 2016 & Journal & & & & & & $\sqrt{ }$ \\
\hline
\end{tabular}

The review included 33 conference proceedings, one web article, and 11 journal articles. These results indicate that the topic is novel and is mainly debated in conferences (Figure 1). 




Figure 1. Source publication details.

The most prolific author is Åsa Fast-Berglund (Chalmers University of Technology, Sweden), with four contributions, followed by David Romero (Tecnológico de Monterrey, Mexico) and Johan Stahre with three contributions (Chalmers University of Technology, Sweden), respectively (Figure 2).



Figure 2. Top contributing authors ( $\geq$ two papers).

Figure 3 illustrates the publication details by year. We noted that 2016 is the year with more publications, followed by 2018 and 2020 . 


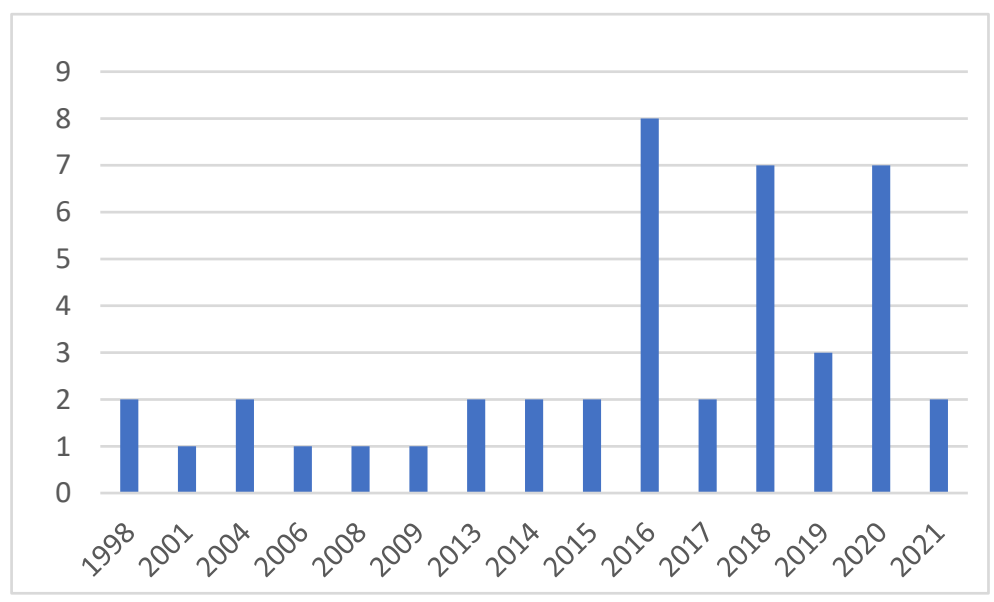

Figure 3. Yearwise publication details.

Human Resource Practices for the Development of Operator 4.0

The extant literature reports six HR practices for the development of OP40, which are staffing, job design, training, performance appraisal system, knowledge management, and compensation. Below, we present each HR practice in detail. Figure 4 graphically summarises the findings.

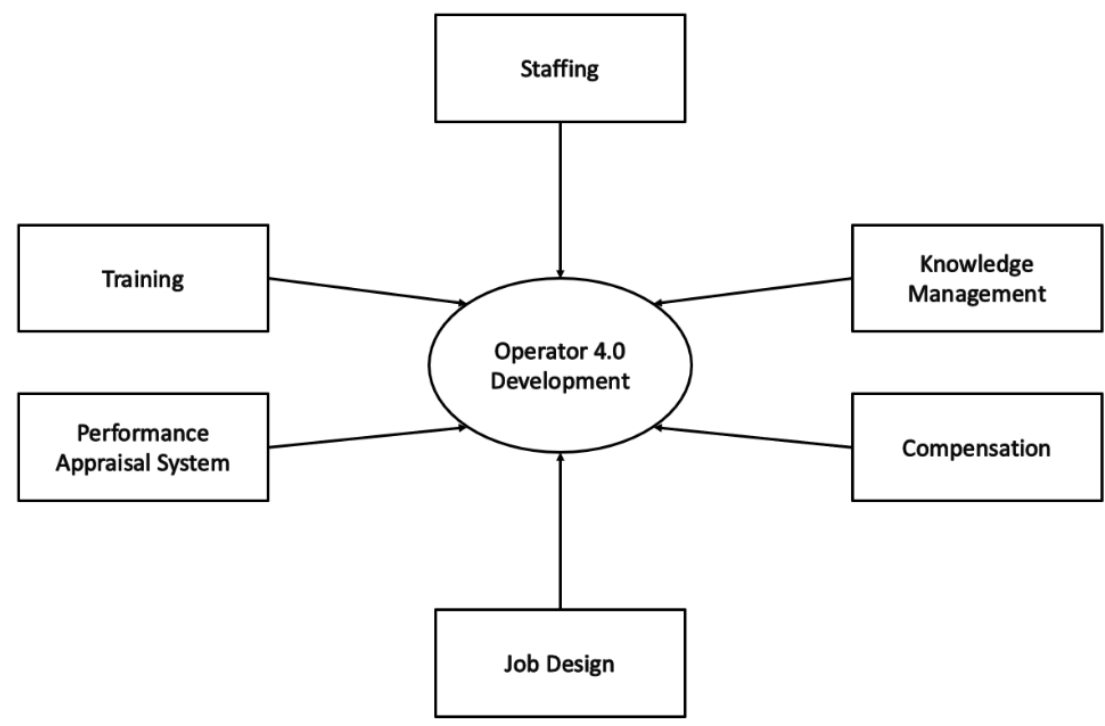

Figure 4. Human resource practices for the development of Operator 4.0.

Staffing. It is the hiring process of suitable personnel for the OP40 role tested with a screening process and evaluated through psychometric tests [27]. For this process, recruiters can use various technologies that support the final decision for a candidate to hire [45]. As a matter of fact, a blockchain-HRM system contributes to the efficient and high transparency of the recruitment process that organisations exploit for an effective decision [46]. The hiring process for OP40 seeks applicants who conduct OP40 activities, including managing I40 technologies autonomously, cooperating with other OP40 and various technologies, and managing production data [47].

Therefore, candidates for OP40 should possess digital skills and fundamental knowledge of programming, web development, and problem-solving. They should be able to work with IT solutions, manage human-machine interfaces, and master the English language. They should also possess essential knowledge of data science activities, including data analysis, descriptive analysis, and problem-solving. Moreover, OP40 should have 
statistical knowledge, organisational and processual understanding, the ability to interact with modern interfaces (human-machine/human-robot), self and time management, and adaptability [48].

Furthermore, applicants for OP40 should possess a positive attitude toward innovation and working in complex environments because I40 adoption changes the nature of work, and OP40 can change their activities during the time [23]. Thus, competencies, such as creativity, flexible thinking, intellectual curiosity, and intellectual curiosity, are valuable for the recruiter of OP40 [48].

Job Design. This HR practice focuses on the characterisation of a job by planning all the relevant tasks. It is called job redesign when the practice modifies a previous job.

The process of job design for OP40 is a challenging path because the I40 adoption changes the way of working down the production and enables novel forms of humanmachine interactions [49]. This implies a need for an extensive design of OP40 role tasks that the operator will perform along the production line. Some scholars overlooked this practice, which is considered the leading cause of OP40 remaining underdeveloped [13]. However, other studies argue that job design for OP40 should be closely linked to the production activities of the I40 organisation because OP40 will conduct operations with the cooperation of these advanced technologies [50]. Thus, the development of OP40 can be a trait as a job redesign of traditional manufacturing workers related to the management of I40 technologies [33]. It should also be focused on flexibility and openness due to the continuous changes in the I40 environment [51].

The extant literature proposes seven potential job designs for OP40 [7,25,32]:

- The super-strength operator is an OP40 who conducts manual tasks-such as handling heavy products - equipped with a smart exoskeleton that reduces worker fatigue and increases operators' productivity [7].

- The smarter operator is an OP40 in charge of managing I40 technologies with an intelligent personal assistant that facilitates the interaction with the I40 technology interfaces and information systems.

- Augmented and virtual operators are OP40s that conduct manual, mental, and maintenance tasks with augmented reality or virtual reality that provides visual guidance for their tasks and reduces mental and physical effort [23].

- The collaborative operator is in charge of working with I40 technologies along the assembly line—-such as cobots of robotised arms—-to maintain constant and efficient organisation's production.

- The analytical operator is the OP40 that examines Big Data extracted from I40 technologies. This operator is in charge of predicting and preventing potential critical events along the assembly line, such as the breaks of machinery pieces or lack of lubrication of the conveyor belt.

Training. This practice refers to the various educational activities that the management organises during and after the I40 adoption to teach OP40 how to manage I40 technologies and collaborate with them [14]. The HR department mainly holds training courses, often assisted by technology experts. Training is designed to include meaningful content to trainees, incorporate practice opportunities, and allow trainees to interact with others [52]. Training programs are more efficient when ongoing and provided both in the presence and digitally [53].

Training should be directly relevant to the OP40 job and increase the variety of skills and knowledge of technology management. Training should also focus on team building and teamwork skills [35]. A tailor-made training strategy for OP40 should analyse the skill profiles of the OP40 and propose adequate training for those lacking skills [54]. Training activities also promote the development of the innovativeness of OP40 because innovative OP40s tend to be able to work smart and overcome uncertainties along the I40 assembly line [55].

HR department often couples training with mentorship or coaching activities, where experienced workers train young workers by supporting them during operations and in 
case of mistakes or technology problems [56]. The development of OP40 can benefit from this practice because novel OP40s can reach a higher level of production activity knowledge, problem-solving skills, and technology management competencies in a comfortable environment $[24,57]$.

Training is a valuable HR practice to avoid the loss of knowledge production in I40 organisations. Since I40 automation replaces several outdated positions, training can requalify traditional manufacturing workers to an OP40, capable of managing I40 technologies and having a high level of product knowledge [58,59]. Therefore, training plays a key in transforming traditional manufacturing workers to the OP40 [60].

Some studies related to the training for I40 technologies are focused on the concept of learning factories [61]. Learning factories pursue an action-oriented approach, where OP40 acquires competencies through structured self-learning processes in a production-technological learning environment. Thus, learning factories integrate different teaching methods to move the teaching/learning processes closer to real industrial problems [61].

As a matter of fact, virtual reality and augmented reality enable an interactive involvement, where OP40 can train the conduction of activities to work with technologies or simulated assembly objects [62]. This learning method facilitates competence development through structured self-learning processes to solve known problems and learn problemsolving processes $[61,63]$ proposed role game-based industrial learning with interactive simulation environments. They claimed that fast and cost-efficient digital training could reduce the need for real hands-on practice and facilitate integrating a broader range of realistic training scenarios.

Performance Appraisal System. This HR practice systematically evaluates employee performance across various performance dimensions [64]. It effectively aligns employee work behaviours with organisational goals. In I40 organisations, OP40 should receive performance feedback regularly [13]. Thus, they know how well they have performed concerning the organisation's standards and concerning others' performance [12].

Moreover, this system is a dynamic and iterative process designed to enhance employee capability and organisational productivity because it allows detecting those workers performing below standards by comparing their actual performance with the standards. If a worker performs below standard, other HR practices—such as vocational courses-can be provided to train their skills to conduct the tasks. Simultaneously, an effective performance management system identifies those higher-performing employees suitable for the extra assignment, merit-based compensation, promotion, or leadership development [13].

In the I40 organisation, a suitable performance appraisal system is based on a resultoriented objective [65] because I40 technologies, such as tracking systems and wearable trackers, allow a punctual measurement of the time spent for each production activity and the number of work units completed, the number of errors and mistakes committed, and the amount of idle time spent [12,34].

By closely monitoring OP40 performance using such technologies, organisations can achieve greater supervisory spans of control while using a democratic way of judging OP40. This reinforces organisational values, norms, and culture and fosters favourable conditions for OP40 development [8].

Furthermore, the literature describes two assessments to incorporate in a performance appraisal system to evaluate OP40 cognitive capabilities and load. Cognitive abilities tests match an operator's cognitive abilities with the mental demands and cognitive skills needed for performing a job [66]. Advanced trained classifiers use various machine learning techniques to measure in real-time the operator's cognitive performance and load to identify when an assisted/enhanced action is necessary [67].

Knowledge Management. It regards obtaining, organising, processing, re-utilising, and transferring knowledge among employees and making knowledge available to all organisations' members [68]. I40 technologies automate various production activities [26], potentially creating a lack of production activity knowledge for OP40. Thus, effective knowledge management is crucial to maintain a high level of knowledge of production ac- 
tivities [69]. Knowledge management for OP40 should include accurate and relevant information for the operations [70]. This is possible by an easily accessible platform for knowledge sharing that ensures OP40 access to basic knowledge [71]. It can also evolve into a place where good work practices and ways to solve problems are shared within the work community and work machine providers [12].

Moreover, I40 technologies, such as virtual reality and augmented reality, can support knowledge management because their systems incorporate a digital copy of assembly or I40 technology instructions and pictures to help OP40 during the assembly and the maintenance phase [7].

Compensation. The compensation system reflects the contribution of OP40 for efficient production, and it is based on individual, group, and organisational performance [72]. Compensation systems include both monetary and intangible rewards. Intangible rewards-such as recognition for well-done work-are essential to motivate OP40 and promote creativity among the human capital in I40 organisations [33]. Thus, the reward system boosts innovativeness and willingness of learning in I40 organisations [57]. Similarly, tangible rewards, such as profit sharing and additional incentive pay, positively affect OP40 performance [23]. Therefore, an effective compensation system helps retain OP40, requalify traditional manufacturing workers and attract talented workers in the organisations.

Still, I40 organisations can use production data in a compensation system to create an individual employee's task performance, tenures, joined events, superiors' ratings, and peers' ratings and to predict the rate of intention to leave [33]. Thus, compensation systems contribute to address the lack of skilled workforce for the OP40 role and avoid the intention of valid OP40 to leave companies [49]. Moreover, I40 technologies allow collecting more accurate data of the OP40 performance and integrating them in the e-compensation system. With these data, these systems can provide more transparent rewards $[8,13]$. They allow OP40 to check their rewards in autonomy and automate the payroll system [73].

\section{Discussion}

The extant literature of OP40 revealed the need to explore how organisations prepare workers for the OP40 role. Thus, this study claimed that HR practices can educate future OP40 or requalifying traditional production worker to accomplish this novel role. The study findings show that organisations use HR practices to prepare the OP40 to work in I40 organisations, improve the efficiency of operators, and increase their collaboration and individual performance with the aim of a return in terms of profits and productivity. Examples are teamwork, job rotation, and individual variable pay based on performance. Human work will become more versatile and creative. Robots and people will work more closely together than ever before. People will use their unique abilities to innovate, collaborate, and adapt to new situations. They will handle challenging tasks with knowledge-based reasoning.

We summarised six HR practices for OP40 by conducting a systematic literature review. The HR practice of staffing involves seeking novel employees who have proper digital and analytical skills for conducting OP40 activities. To this end, the literature describes OP40 job descriptions that a recruiter can follow to hire valid applications [27]. Further studies should create a specific list of competencies that OP40 should possess and recruiters can use during the hiring process.

The HR practice of job design for OP40 is underdeveloped. We only found a study presenting seven potential job designs for the OP40 [7]. Thus, it remains unclear how OP40 interacts with I40 technologies in I40 organisations. Further research is needed to overcome this lack, mainly qualitative studies—such as case study and ethnography—that have a robust exploratory power.

HR practices for the development and the requalification of traditional manufacturing workers to OP40 are training, knowledge management, and performance appraisal systems. Researchers extensively debated the HR practice of training [35] and how I40 technologies support this practice for OP40 development [15]. A future research avenue is to analyse 
the time needed for organisations to requalify traditional manufacturing workers in OP40. Instead, knowledge management and performance appraisal system are less reported. Since I40 automation potential reduces the knowledge of production activities of OP40, there is the risk of an inefficient OP40 performance. Therefore, further studies are needed to explore how these HR practices can mitigate this issue and how I40 technologies can support these HR practices.

In addition, depending on changing corporate structures, novel performance measurement tools are emerging. These tools privilege performance management, which rewards employees for their hard work rather than for their seniority. We also noted that a complex role, such as OP40, requires managers who empower and inspire them and management that opens to OP40 feedback and to regularly talk about company goals.

Compensation can be used to retain valid OP40 by tangible and intangible rewards. In these regards, further studies can investigate the characteristics of meaningful compensation systems to sustain an outstanding and ongoing performance of the OP40.

Therefore, we conclude by answering the research question: the HR practices for the development of OP40 are staffing, job design, training, performance appraisal system, knowledge management, and compensation.

\section{A research Agenda to Advance the Topic of Human Resources Practices for Operator 4.0 Development and Implications for Practitioners}

Since HR practices for the development of OP40 are in an infant stage, we summarised various practices by conducting a systematic literature review. The HR department is increasingly called upon to promote the cultural, technological, and organisational change required by organisations, overcoming internal resistance and putting the employee at the centre of change. The main research avenue of this study was to investigate how organisations can use these HR practices to develop OP40 and create a theory on this phenomenon. Our study illustrated six HR practices for OP40 in literature, but we did not explore whether and how these HR practices are used in combination to shape OP40. This research question should be addressed to advance this research stream. To this end, we propose a research agenda composed of four phases [74]. Figure 5 graphically summarises the research agenda.



Figure 5. A proposed research agenda.

The exploratory phase is devoted to shaping the theoretical foundations of HR practices for OP40, which we addressed with this literature review. We encourage researchers to conduct a further qualitative synthesis of the literature or systematic literature review using various databases—such as WoS, EBSCO, Scopus, and Google Scholar-and reviewing articles in various languages. In addition, we foster further literature reviews for each of the six HR practices to deepen the theoretical foundation and avoid omitting suitable stud- 
ies on the topic. Particularly further studies are needed for the knowledge management, job description, and performance appraisal system that are less studied.

Phase II covers the process to build a grounded theory that explains how organisations use HR practices for OP40 development. Grounded theory is a suitable method to develop context-based theories and is particularly appropriate in areas where prior knowledge of the research field does not lead to pre-formulated hypotheses. Surveys and interviews with experts are valid methods to employ in this phase. Our study can be used as a base for survey items and a starting point to create a track interview.

These theories are then tested in phase III by empirical studies, action research, and surveys to determine if they are suited for organisations' application. After the implementation, the concepts have to be continuously reviewed and benchmarked for continuous improvement to maintain a valid theory of HR practices for OP40.

Furthermore, our study has implications for practitioners. HR departments and temp agencies use this study as a guideline for the HR practices to recruit, requalify, and manage OP40.

Practitioners who want to implement a socially sustainable factory need to allocate resources to educate traditional manufacturing workers using I40 technologies because they cannot conduct the OP40 role. They have to implement I40 technologies and manage the development of workers in parallel. Furthermore, they should invest in the design of ad hoc policies to search and select applicants with digital profiles and requalify workers already available through training.

Policymakers who want to develop a national programme for supporting manufacturing organisations should allocate federal grants both for purchasing technologies and for the development of OP40. Thus, organisations can adopt I40 technologies to increase production efficiency and empower workers' roles, instead of using I40 automaton to reduce staff cost and the number of workers.

\section{Conclusions}

OP40 is the worker operating in I40 organisations that manage I40 technologies and is also aided by these technologies. The extant literature of OP40 primarily concentrated on enabling I40 technologies for this role and the various qualitative benefits for OP40. However, organisations encounter issues to educate traditional manufacturing workers for this novel role and hire novel workers for this role. We addressed this gap by conducting a systematic literature review to summarise HR practices for OP40 development. The review revealed six HR practices for developing an OP40: staffing, job design, training, performance appraisal system, knowledge management, and compensation. We also proposed a research agenda to advance this research stream for the development of a theory that explains whether and how organisations use HR practices for OP40.

The study has a limitation. We conducted a systematic literature review on Scopus, Google Scholar, and Science Direct, analysing only English papers. Future studies should address our study limitation by conducting a systematic literature review in different databases - such as WoS, EBSCO, Scopus, and Google Scholar-analysing papers in various languages.

Author Contributions: E.G.M., I.B. have contributed equally to the paper. All authors have read and agreed to the published version of the manuscript.

Funding: This research received no external funding.

Institutional Review Board Statement: Not applicable.

Informed Consent Statement: Not applicable.

Data Availability Statement: Data are not publicly available, though the data may be made available on request from the corresponding author.

Conflicts of Interest: The authors declare no conflict of interest. 


\section{References}

1. Birkel, H.; Müller, J.M. Potentials of Industry 4.0 for supply chain management within the triple bottom line of sustainability-A systematic literature review. J. Clean. Prod. 2021, 289, 125612. [CrossRef]

2. Margherita, E.G.; Braccini, A.M. Organizational impacts on sustainability of Industry 4.0: A systematic literature review from empirical case studies. In Lecture Notes in Information Systems and Organisation; Springer: Cham, Germany, 2020; pp. 173-186.

3. Kagermann, H.; Wolfgang, W.; Helbig, J. Recommendations for Implementing the Strategic Initiative INDUSTRIE 4.0. Working Group; Acatech: Frankfurt Am Main, Germany, 2013.

4. Müller, J.M.; Buliga, O.; Voigt, K.-I. Fortune favors the prepared: How SMEs approach business model innovations in Industry 4.0. Technol. Forecast. Soc. Chang. 2018, 132, 2-17. [CrossRef]

5. Kang, H.S.; Lee, J.Y.; Choi, S.; Kim, H.; Park, J.H.; Son, J.Y.; Kim, B.H.; Noh, S.D. Smart manufacturing: Past research, present findings, and future directions. Int. J. Precis. Eng. Manuf. Technol. 2016, 3, 111-128. [CrossRef]

6. Breque, M.; Lars, D.N.; Athanasios, P. Industry 5.0. Available online: https://doi.org/10.2777/308407 (accessed on 15 April 2021).

7. Romero, D.; Stahre, J.; Taisch, M. The Operator 4.0: Towards socially sustainable factories of the future. Comput. Ind. Eng. 2020, 139, 106128. [CrossRef]

8. Li, D.; Fast-Berglund, Å.; Paulin, D. Current and future Industry 4.0 capabilities for information and knowledge sharing. Int. J. Adv. Manuf. Technol. 2019, 105, 3951-3963. [CrossRef]

9. Margherita, E.G.; Braccini, A.M. Exploring the socio-technical interplay of Industry 4.0: A single case study of an Italian manufacturing organisation. In CEUR Workshop, Proceedings of the 6th International Workshop on Socio-Technical Perspective in IS Development (STPIS 2020), Grenoble, France, 8-9 June 2020; CEUR-WS: Aachen, Germany, 2020.

10. Romero, D.; Stahre, J.; Wuest, T.; Noran, O.; Bernus, P.; Fast-Berglund, Å.; Gorecky, D. Towards an Operator 4.0 typology: A human-centric perspective on the fourth industrial revolution technologie. In Proceedings of the 46th International Conference on Computers \& Industrial Engineering (CIE46), Tianjin, China, 29-31 October 2016.

11. Mikalef, P.; Pappas, I.O.; Krogstie, J.; Giannakos, M. Big data analytics capabilities: A systematic literature review and research agenda. Inf. Syst. E Bus. Manag. 2018, 16, 547-578. [CrossRef]

12. Kaasinen, E.; Schmalfuß, F.; Özturk, C.; Aromaa, S.; Boubekeur, M.; Heilala, J.; Heikkilä, P.; Kuula, T.; Liinasuo, M.; Mach, S.; et al. Empowering and engaging industrial workers with Operator 4.0 solutions. Comput. Ind. Eng. 2020, 139, 105678. [CrossRef]

13. Shamim, S.; Cang, S.; Yu, H.; Li, Y. Management approaches for Industry 4.0. In Proceedings of the IEEE Congress on Evolutionary Computation, CEC 2016, Vancouver, BC, Canada, 24-29 July 2016.

14. Braccini, A.; Margherita, E. Exploring organizational sustainability of Industry 4.0 under the triple bottom line: The case of a manufacturing company. Sustainability 2019, 11,36. [CrossRef]

15. Segura, Á.; Diez, H.V. Barandiaran, I.; Arbelaiz, A.; Álvarez, H.; Simões, B.; Posada, J.; García-Alonso, A.; Ugarte, R. Visual computing technologies to support the Operator 4.0. Comput. Ind. Eng. 2020, 139, 105550. [CrossRef]

16. Frey, C.B.; Osborne, M.A. The future of employment: How susceptible are jobs to computerisation? Technol. Forecast. Soc. Chang. 2017, 114, 254-280. [CrossRef]

17. Bonekamp, L.; Sure, M. Consequences of Industry 4.0 on human labour and work organisation. J. Bus. Media Psychol. 2015, 6 , 33-40.

18. Kamble, S.S.; Gunasekaran, A.; Sharma, R. Analysis of the driving and dependence power of barriers to adopt industry 4.0 in Indian manufacturing industry. Comput. Ind. 2018, 101, 107-119. [CrossRef]

19. Liao, Y.; Deschamps, F.; Loures, E.D.F.R.; Ramos, L.F.P. Past, present and future of Industry 4.0-A systematic literature review and research agenda proposal. Int. J. Prod. Res. 2017, 55, 3609-3629. [CrossRef]

20. Prause, G.; Atari, S. On sustainable production networks for Industry 4.0. Entrep. Sustain. Issues 2017, 4, 421-431. [CrossRef]

21. Imperatori, B.; Bissola, R.; Butera, F.; Bodega, D. Work and HRM in the 4.0 era: Insights and research directions. Studi Organ. 2020, 2, 9-26. [CrossRef]

22. Bulte, A. What is Industry 4.0 and what are its implications on HRM practices? In Proceedings of the 11th IBA Bachelor Thesis Conference, Enschede, The Netherlands, 10 July 2018; pp. 1-23.

23. Sivathanu, B.; Pillai, R. Smart HR 4.0-How industry 4.0 is disrupting HR. Hum. Resour. Manag. Int. Dig. 2018, 26, 7-11. [CrossRef]

24. Prieto, I.M.; Pérez-Santana, M.P. Managing innovative work behavior: The role of human resource practices. Pers. Rev. 2014, 43, 184-208. [CrossRef]

25. Zolotová, I.; Papcun, P.; Kajáti, E.; Miškuf, M.; Mocnej, J. Smart and cognitive solutions for Operator 4.0: Laboratory H-CPPS case studies. Comput. Ind. Eng. 2020, 139, 105471. [CrossRef]

26. Ruppert, T.; Jaskó, S.; Holczinger, T.; Abonyi, J. Enabling technologies for Operator 4.0: A survey. Appl. Sci. 2018, 8, 1650. [CrossRef]

27. Romero, D.; Bernus, P.; Noran, O.; Stahre, J.; Berglund, Å.F. The operator 4.0: Human cyber-physical systems \& adaptive automation towards human-automation symbiosis work systems. In IFIP Advances in Information and Communication Technology; Springer: New York, NY, USA, 2016; Volume 488, pp. 677-686.

28. Stern, H.; Becker, T. Concept and evaluation of a method for the integration of human factors into human-oriented work design in cyber-physical production systems. Sustainability 2019, 11, 4508. [CrossRef] 
29. Sorge, A.; Streeck, W. Industrial relations and technical change: The case for an extended perspective. In New Technology and Industrial Relations; Hyman, R., Streeck, W., Eds.; Basil Blackwell: Oxford, UK, 1988; pp. 19-57.

30. Romero, D.; Wuest, T.; Stahre, J.; Gorecky, D. Social factory architecture: Social networking services and production scenarios through the social internet of things, services and people for the social Operator 4.0. IFIP Adv. Inf. Commun. Technol. 2017, 513, 265-273. [CrossRef]

31. Tarrar, M.; Thorvald, P.; Fasth-berglund, A.; Romero, D. Challenges for the Operator 3.0 addressed through the enabling technologies of the Operator 4.0. In Advances in Production Management Systems. Towards Smart and Digital Manufacturing; Proceedings of the APMS 2020 IFIP Advances in Information and Communication Technology, Novi Sad, Serbia, 30 August-3 September 2020; Lalic, B., Majstorovic, V., Marjanovic, U., von Cieminski, G., Eds.; Springer: Cham, Germany, 2020; Volume 592, pp. 1-8.

32. Romero, D.; Mattsson, S.; Fast-Berglund, Åsa; Wuest, T.; Gorecky, D.; Stahre, J. Digitalizing occupational health, safety and productivity for the Operator 4.0. Secur. Educ. Crit. Infrastruct. 2018, 536, 473-481. [CrossRef]

33. Gan, J.L.; Yusof, H.M. Industrial revolution 4.0: The human resource practices. Int. J. Recent Technol. Eng. 2019, 8, 620-624.

34. Margherita, E.G.; Braccini, A.M. Industry 4.0 Technologies in Flexible Manufacturing for Sustainable Organisational Value: Reflections from a Multiple Case Study of Italian Manufacturers. Inf. Syst. Front. 2020. [CrossRef]

35. Margherita, E.G.; Braccini, A.M. Managing the fourth industrial revolution: A competence framework for smart factory. In Recent Advances in Computational Optimization; Springer: Cham, Germany, 2021; pp. 389-402.

36. Wuest, T.; Romero, D.; Cavuoto, L.A.; Megahed, F.M. Empowering the workforce in Post-COVID-19 smart manufacturing systems. Smart Sustain. Manuf. Syst. 2020, 4, 5. [CrossRef]

37. Papcun, P.; Kajati, E.; Koziorek, J. Human machine interface in concept of Industry 4.0. In Proceedings of the 2018 World Symposium on Digital Intelligence for Systems and Machines (DISA), Kosice, Slovakia, 23-25 August 2018; pp. 289-296. [CrossRef]

38. Ras, E.; Wild, F.; Stahl, C.; Baudet, A. Bridging the skills gap of workers in Industry 4.0 by human performance augmentation tools. In Proceedings of the 10th International Conference on Predictive Models in Software Engineering, Turin, Italy, 17 September 2014; ACM: New York, NY, USA, 2017; Volume Part F128530, pp. 428-432.

39. Quint, F.; Sebastian, K.; Gorecky, D. A Mixed-reality learning environment. Procedia Comput. Sci. 2015, 75, 43-48. [CrossRef]

40. Schneider, P. Managerial challenges of Industry 4.0: An empirically backed research agenda for a nascent field. Rev. Manag. Sci. 2018, 12, 803-848. [CrossRef]

41. Webster, J.; Watson, R.T. Analysing the past to prepare for the future: Writing a literature review. MIS Q. 2002, 26, 129-147.

42. Scott-Findlay, S.; Estabrooks, C.A. Mapping the organizational culture research in nursing: A literature review. J. Adv. Nurs. 2006, 56, 498-513. [CrossRef] [PubMed]

43. Flick, U. Introducing Research Methodology: A Beginner's Guide to Doing a Research Project; SAGE Publications: Thousand Oaks, CA, USA, 2015.

44. Okoli, C.; Schabram, K. A guide to conducting a systematic literature review of information systems research. SSRN Electron. J. 2010, 10, 2. [CrossRef]

45. Marvel, M.R.; Davis, J.L.; Sproul, C.R. Human capital and entrepreneurship research: A critical review and future directions. Entrep. Theory Pr. 2014, 40, 599-626. [CrossRef]

46. Onik, M.; Miraz, M.; Kim, C.-S. A recruitment and human resource management technique using blockchain technology for Industry 4.0. In Proceedings of the Smart Cities Symposium 2018, Chicago, IL, USA, 17-18 January 2018; p. 3.

47. Waschull, S.; Bokhorst, J.A.C.; Wortmann, J.C. Impact of technology on work: Technical functionalities that give rise to new job designs in Industry 4.0. In Lecture Notes in Control and Information Sciences; Springer: Cham, Germany, 2017 ; pp. $274-281$.

48. Vrchota, J.; Mařiková, M.; Řehoř, P.; Rolínek, L.; Toušek, R. Human resources readiness for Industry 4.0. J. Open Innov. Technol. Mark. Complex. 2019, 6, 3. [CrossRef]

49. Alhajjar, A.A.; Muhammed Kassim, R.; Raju, E.; Alnachef, T. Driving Industry 4.0 business through talent man-agement of human resource system: The conceptual framework for banking industry. World J. Res. Rev. 2018, 7, 53-57.

50. Kadir, B.A.; Broberg, O. Human-centered design of work systems in the transition to industry 4.0. Appl. Ergon. 2021, 92, 103334. [CrossRef] [PubMed]

51. Gabriel, M.; Pessel, E. Industry 4.0 and sustainability impacts: Critical discussion of sustainability aspects with a special focus on future of work and ecological consequences. Ann. Fac. Eng. Hunedoara 2016, 14, 131-136.

52. Kraiger, K.; McLinden, D.; Casper, W.J. Collaborative planning for training impact. Hum. Resour. Manag. 2004, 43, 337-351. [CrossRef]

53. Santhanam, R.; Sasidharan, S.; Webster, J. Using self-regulatory learning to enhance e-learning-based information technology training. Inf. Syst. Res. 2008, 19, 26-47. [CrossRef]

54. Hecklau, F.; Galeitzke, M.; Flachs, S.; Kohl, H. Holistic approach for human resource management in Industry 4.0. Procedia CIRP 2016, 54, 1-6. [CrossRef]

55. Van Der Sluis, L.E. Designing the workplace for learning and innovation. Dev. Learn. Organ. Int. J. 2004, 18, 10-13. [CrossRef]

56. Fettig, K.; Gacic, T.; Koskal, A.; Kuhn, A.; Stuber, F. Impact of Industry 4.0 on organizational structures. In Proceedings of the 2018 IEEE International Conference on Engineering, Technology and Innovation (ICE/ITMC), Stuttgart, Germany, 17-20 June 2018; pp. 1-8. 
57. Chen, C.-J.; Huang, J.-W. Strategic human resource practices and innovation performance-The mediating role of knowledge management capacity. J. Bus. Res. 2009, 62, 104-114. [CrossRef]

58. Benešová, A.; Tupa, J. Requirements for education and qualification of people in Industry 4.0. Procedia Manuf. 2017, 11, 2195-2202. [CrossRef]

59. Gehrke, L.; Kühn, A.T.; Rule, D.; Moore, P.; Bellmann, C.; Siemes, S.; Dawood, D.; Lakshmi, S.; Kulik, J.; Standley, M. A discussion of qualifications and skills in the factory of the future: A German and American perspective. VDI ASME Ind. 2015, 4, 1-28.

60. Rada, M. Industry 5.0-From Virtual to Physical. Available online: https://www.linkedin.com/pulse/industry-50-from-virtualphysical-michael-rada/ (accessed on 11 September 2017).

61. Tisch, M.; Hertle, C.; Cachay, J.; Abele, E.; Metternich, J.; Tenberg, R. A systematic approach on developing action-oriented, competency-based learning factories. Procedia CIRP 2013, 7, 580-585. [CrossRef]

62. Peruzzini, M.; Grandi, F.; Pellicciari, M. Exploring the potential of Operator 4.0 interface and monitoring. Comput. Ind. Eng. 2020, 139, 105600. [CrossRef]

63. Mavrikios, D.; Papakostas, N.; Mourtzis, D.; Chryssolouris, G. On industrial learning and training for the factories of the future: A conceptual, cognitive and technology framework. J. Intell. Manuf. 2011, 24, 473-485. [CrossRef]

64. Fletcher, C. Performance appraisal and management: The developing research agenda. J. Occup. Organ. Psychol. 2001, $74,473-487$. [CrossRef]

65. Denisi, A.S.; Pritchard, R.D. Performance appraisal, performance management and improving individual performance: A motivational framework. Manag. Organ. Rev. 2006, 2, 253-277. [CrossRef]

66. Militello, L.G.; Hutton, R.J.B. Applied cognitive task analysis (ACTA): A practitioner's toolkit for understanding cognitive task demands. Ergonomics 1998, 41, 1618-1641. [CrossRef]

67. Woźniak, M.; Graña, M.; Corchado, E. A survey of multiple classifier systems as hybrid systems. Inf. Fusion 2014, 16, 3-17. [CrossRef]

68. Davenport, T.H.; Prusak, L. Working Knowledge: How Organisations Manage What They Know; Harvard Business School Press: Boston, MA, USA, 1998.

69. Pinzone, M.; Albè, F.; Orlandelli, D.; Barletta, I.; Berlin, C.; Johansson, B.; Taisch, M. A framework for operative and social sustainability functionalities in human-centric cyber-physical production systems. Comput. Ind. Eng. 2020, 139, 105132. [CrossRef]

70. Roblek, V.; Meško, M.; Krapež, A. A complex view of Industry 4.0. SAGE Open 2016, 6, 1-11. [CrossRef]

71. Gerdin, M.B.; Fast-Berglund, L.D.; Palmquist, A. Knowledge strategies for organization 4.0-A workforce centric approach. In Advances in Production Management Systems. Towards Smart and Digital Manufacturing, Proceedings of the APMS 2020, IFIP Advances in Information and Communication Technology, Novi Sad, Serbia, 30 August-3 September 2020; Lalic, B., Majstorovic, V., Marjanovic, U., von Cieminski, G., Romero, D., Eds.; Springer: Cham, Germany, 2020; Volume 592, pp. 31-36.

72. Wolf, M.; Kleindienst, M.; Ramsauer, C.; Zierler, C.; Winter, E. Current and future industrial challenges: Demo-graphic change and measures for elderly workers in industry 4.0. Ann. Fac. Eng. Hunedoara Int. J. Eng. 2018, 16, 67-76.

73. Johnson, R.D.; Stone, D.L.; Lukaszewski, K.M. The evolution of the field of human resource information systems: Co-evolution of technology and hr processes. Commun. Assoc. Inf. Syst. 2016, 38, 533-553. [CrossRef]

74. Oesterreich, T.D.; Teuteberg, F. Understanding the implications of digitisation and automation in the context of Industry 4.0: A triangulation approach and elements of a research agenda for the construction industry. Comput. Ind. 2016, 83, 121-139. [CrossRef] 